\title{
Correlation between Serum Ferritin and Proteinuria as Marker of Diabetic Nephropathy Stage in Type 2 Diabetic Patients
}

Mohamed A .Mohamed, Saddam A.A. Hassan, Nabil E. Khattab, Samar M. Atiaa, Abdel Moneim A. Abdel Moneim

\begin{abstract}
Department of Internal medicine, Faculty of Medicine Benha University, Egypt.
\end{abstract}

Correspondence to: Samar M. Atiaa, Department of Internal medicine, Faculty of Medicine Benha University, Egypt.

Email:

samar.atiaa89@yahoo.com

Received: 16 June 2021

Accepted: 25 July 2021

\begin{abstract}
Background: Increased iron reserves in the body have been linked to the development of type 2 diabetes, as well as diabetic nephropathy, retinopathy and vascular dysfunction. Serum ferritin has been related to the occurrence of CKD. Aim of study :Aiming to look into the link between serum ferritin and proteinuria as a diabetic nephropathy marker in type 2 diabetic patients. Subjects and methods: It involved 50 individuals of matched age and gender who were split into two groups: 25 type 2 diabetic patients with proteinuria and 25 apparently healthy volunteers (hospital personnel) with no history of diabetes who served as the control group. The enzyme-linked immunosorbent assay (ELISA) kit for quantitative detection of human serum ferritin was used to estimate serum ferritin. Results: In the current study, serum ferritin levels in
\end{abstract} diabetics with proteinuria showed a high significant rise when compared to the control group. $(\mathrm{p}<0.001)$. The comparative present study, the mean \pm SD of diabetic patients with nephropathy, serum ferritin was $513.91 \pm 260.06 \mathrm{ng} / \mathrm{ml}$ while that of control $133.42 \pm 186.66$ $\mathrm{ng} / \mathrm{ml}$. The current study revealed a high significant positive relationship between ferritin and $24 \mathrm{~h}$ protein in diabetic patients with nephropathy $(\mathrm{r}=0.512, \mathrm{p}=0.009)$, show no significant positive association in control group $(\mathrm{r}=0.02, \mathrm{p}=0.94)$. Conclusion: serum ferritin can be considered as an independent predicting marker of diabetic nephropathy as well as an excellent diagnostic marker for patients with clinical diabetic nephropathy.

Keyword: Diabetic nephropathy, ferritin , proteinuria.

\section{Introduction}


Type 2 diabetes mellitus and its comorbidities have become a chief community health problem worldwide. In 2010 , it was assessed that 285 million people were suffering from T2DM. According to International Diabetes Federation, the prevalence estimate is predicted to approach 552 million by 2030 (1). A measure of the body's iron reserves is serum ferritin, an acute phase reactant.

The development of type 2 diabetes, as well as diabetic retinopathy, nephropathy, and vascular dysfunction, has been linked to increased body iron storage and subclinical hemochromatosis (2). For a long time, serum ferritin has been used as an indicator of total iron reserves. It is related to a greater risk of Type 2 diabetes and the development of reactive oxygen species, so patients with diabetes who have impaired glycemic control should expect elevated serum ferritin levels (3). Diabetic nephropathy, which affects about $40 \%$ of type 2 diabetics, is the most common cause of kidney failure in persons starting renal replacement treatment. Increased urine albumin excretion (UAE) in the absence of other renal disorders raises the risk of death, primarily from cardiovascular reasons (4).

Proteinuria is a characteristic hallmark of diabetic kidney disease (DKD) and a distinct risk factor for the progression of both renal and cardiovascular disease. Diabetic kidney disease (DKD) is the biggest cause of chronic and end-stage kidney disease internationally. Proteinuria is a DKD clinical characteristic that helps us target our treatment, it is a symptom indicating the severity of the condition (5).

\section{Subjects and methods}

This case-control study was performed at the Department of Internal MedicineBenha University Hospitals. It was carried out on 50 individuals of matched age and gender, 25 of whom were type 2 diabetics with proteinuria and 25 of whom appeared to be healthy with no history of diabetes who worked as control group in period from February 2020 to 
October 2020. The study was authorized by the Faculty of Medicine Benha University's Ethical Research Committee.

This group involved 25 apparently healthy volunteers selected from those working in auxiliary jobs in Benha University Hospitals, (13 males and 12 females) whose ages range from 35-60 years $(50.8+6.95$ years $)$. The control group of healthy volunteers was chosen so as to have no history of arterial hypertension, diabetes, neoplastic, cardiovascular, lung, renal, endocrine or central nervous system disorder. None of these subjects were under any medical treatment.

* Group II (Patients' Group): This group involved 25 adult patients with type 2 DM having proteinuria as a marker of diabetic nephropathy (14 males and 11 females) whose ages range from 35-60 years $(52.12+5.62$ years $)$. The diagnosis was based on the ADA criteria for diagnosis of DM. Inclusion criteria: all patients were type 2 diabetes. Exclusion criteria: the following patients were excluded from the study: any hepatic disease as liver cirrhosis, increased liver aminotransferase, and viral hepatitis or
The subjects of the study were divided into the following categories:

\section{* Group I (Control Group):}

patients with type 1 diabetes mellitus or malignant diseases of any organ or active inflammatory diseases or other known major diseases, CKD or a history of renal disease or hematological disease.

\section{Sample collection}

\section{Serum samples}

Five milliliters of venous blood were taken after 6-8 hours fasting with complete aseptic precautions in plain vacutainer (red-topped) tubes. The collected fasting sample was divided into two portions: - $0.3 \mathrm{ml}$ on EDTA for determination of $\mathrm{HbAlc}$ after clotting, the rest of the sample was centrifuged (at 1000 $\mathrm{xg}$ for 15 minutes). The serum was split into two identical aliquots. One was used for rapid testing of fasting serum glucose level, serum creatinine, CRP, and ESR, and the other aliquot was stored at $-20^{\circ} \mathrm{C}$ for subsequent assay of serum ferritin. Repeated freezing and thawing was avoided. Another 2 millimeters venous blood sample were taken 2 hours later for post prandial serum glucose level measurement. 


\section{Urine Sample}

The collection method for a 24-hour urine collection usually starts first thing in the morning with the first morning void being

\section{Routine tests:}

- Fasting serum glucose and serum creatinine were done using Dimension clinical chemistry system auto analyzer Siemens

- Glycated hemoglobin (HbA1c): was done by StanbioGlycohemoglbin procedure through quantitative Colorimetric method

\section{Special investigations:}

Estimation of 24 hour urinary protein : through turbid metric method by precipitation

Estimation of serum ferritin: ELISA kit for quantitative detection of human serum A report form was used to capture the clinical data. The computer programme SPSS (Statistical package for social science) (IBM Corp., 2011) was used to tabulate and analyse the data. Windows version 20.0, IBM SPSS Statistics (Armonk, NY: IBM Corp) to obtain:

\section{Descriptive statistics}

The following descriptive statistics were generated for the data: discarded and then collecting all of the pee for the remaining 24-hour period. During this time, the sample was kept refrigerated.

\section{Methods}

Glomerular Filtration Rate (GFR) Estimation: GFR was calculated using the Cockcroft Gault equations method $\operatorname{GFR}(\mathrm{ml} / \mathrm{min})=\frac{(140-\text { age }(\text { year })) \times(\text { weight }(\mathrm{Kg}))}{72 \times \text { s.creatinine }(\mathrm{mg} / \mathrm{dl})} \times 0.85$ if female

- ESR, CRP, urine analysis ferritin, supplied by William James house Cowley Rd, Cambridge CB4 OWX, UK, was used to estimate serum ferritin.

\section{Statistical methods: Management of data}

1. Mean and Standard deviation for quantitative data, the median and interquartile range (IQR) are used.

2. Qualitative data frequency and distribution

\section{Analytical statistics}

After proving their non-normality with the $\mathrm{K}-\mathrm{S}$ test, the importance of difference was examined using one of the following tests in the statistical comparison between the 
various groups (One-Sample

Kolmogorov-Smirnov Test) of normality.

1- Mann-Whitney test: - When comparing the mean of two groups of non-parametric quantitative data, this function is used.

2- The Chi square test (X2-value) and the fisher exact test were used to compare categorical data between groups (FET).

3- Correlation coefficient: - to discover correlations between variables in all analyses, a P value below 0.05 was regarded statistically significant $(*)$, whereas a $\mathrm{P}$ value more than 0.05 regarded statistically insignificant whereas a $\mathrm{P}$ value under 0.01 was regarded highly significant $(* *)$.

\section{Results}

This case control study was performed at the department of internal medicine in Benha University Hospitals. It was conducted on 50 participants of matched age and gender, 25 of whom were type 2 diabetic patients with proteinuria and 25 were apparently healthy volunteers (hospital personnel) with no history of diabetes who served as the control group from February to October 2020. Age and gender of cases and healthy volunteers are summarized in (table1). No significant differences have been found in age and gender among the cases and the controls. Statistical significant differences have been found regarding serum ferritin and 24 $\mathrm{h}$ urinary protein among the cases and controls (table2), (figure1). Among the cases and the controls, there have been statistically significant differences as regards ESR 1h, ESR 2h, CRP, HbA1c, 24h protein, FBG, PPG, serum creatinine, serum ALT, serum Albumin, serum ferritin, eGFR , CRP, albumin in urine but no significant difference with volume of urine (table3), (table4) ,(figure2) ,(figure3). A high significant positive statistical relationship between ferritin and 24 hour urinary protein among case group is present (table5) (figure4), but no significant relationship between ferritin and 24hour urinary protein has been found among control group (table6). There has been a significant relationship among ferritin and $\mathrm{HbA1c}$, creatinine, eGFR, and albumin in urine but with no significant relationship with other variables among case group (table7), no significant relationship among ferritin and $\mathrm{HbA} 1 \mathrm{c}$, creatinine, eGFR, albumin in urine and other variables has been found among control group (table8) 
Table1: Demographic description of included subjects

\begin{tabular}{ccccccc}
\hline & \multicolumn{2}{c}{ Case group (25) } & \multicolumn{2}{c}{ Control group (25) } & Statistical & P value \\
& No & $\mathbf{\%}$ & No & $\mathbf{\%}$ & test (x2) & \\
\hline Sex & 14 & 56.0 & 13 & 52.0 & 0.08 & 0.78 \\
Male & 11 & 44.0 & 12 & 48.0 & St t test & P value \\
Female & mean & SD & mean & SD & St & 0.46 \\
Age (years) & 52.12 & 5.62 & 50.8 & 6.95 & 0.74 & \\
\hline
\end{tabular}

Table2: Comparison between case and control groups according to 24hour protein and ferritin

\begin{tabular}{|c|c|c|c|c|c|c|}
\hline & \multicolumn{2}{|c|}{ Case group (25) } & \multicolumn{2}{|c|}{ Control group (25) } & \multirow{2}{*}{$\begin{array}{l}\text { Statistical } \\
\text { test (St t) }\end{array}$} & \multirow{2}{*}{$P$ value } \\
\hline & mean & SD & mean & SD & & \\
\hline $\begin{array}{l}\text { 24h protein } \\
\text { (mg/24 hours) }\end{array}$ & 2135.36 & 1127.69 & 60.0 & 19.58 & 9.2 & $<0.001 * *$ \\
\hline Ferritin (ng/ml) & 513.91 & 260.06 & 133.42 & 186.66 & 5.94 & $<0.001 * *$ \\
\hline
\end{tabular}

Table 3: Comparison between case and control groups according to ESR 1h, ESR 2h, CRP, HbA1c,24h protein, FBG, PPG, Creatinine, ALT, Albumin, Ferritin, Volume of urine, eGFR.

\begin{tabular}{|c|c|c|c|c|c|c|}
\hline & \multicolumn{2}{|c|}{ Case group (25) } & \multicolumn{2}{|c|}{ Control group (25) } & \multirow{2}{*}{$\begin{array}{c}\text { Statistical } \\
\text { test (st t) }\end{array}$} & \multirow{2}{*}{$P$ value } \\
\hline & mean & SD & mean & SD & & \\
\hline $\begin{array}{l}\text { ESR 1h } \\
(\mathrm{mm} / \mathrm{hr})\end{array}$ & 49.8 & 18.57 & 15.36 & 3.73 & 9.09 & $<0.001 * *$ \\
\hline $\begin{array}{l}\text { ESR 2h } \\
(\mathbf{m m} / \mathbf{h r})\end{array}$ & 92.2 & 26.26 & 31.64 & 7.77 & 11.06 & $<0.001 * *$ \\
\hline CRP (mg/L) & 25.6 & 21.57 & 5.0 & 0.0 & 4.78 & $<0.001 * *$ \\
\hline HbA1c (\%) & 8.31 & 0.84 & 5.63 & 0.44 & 14.18 & $<0.001 * *$ \\
\hline $\begin{array}{l}\text { 24h protein } \\
\text { (mg/24 hrs) }\end{array}$ & 2135.36 & 1127.69 & 60.0 & 19.58 & 9.2 & $<0.001 * *$ \\
\hline FBG (mg/dl) & 203.48 & 33.7 & 85.16 & 8.53 & 17.02 & $<0.001 * *$ \\
\hline PPG (mg/dl) & 325.4 & 55.3 & 130.12 & 6.2 & 17.55 & $<0.001 * *$ \\
\hline $\begin{array}{l}\text { Creatinine } \\
\text { (mg/dl) }\end{array}$ & 2.66 & 1.55 & 0.83 & 0.15 & 5.88 & $<0.001^{* *}$ \\
\hline ALT (IU/ml) & 30.88 & 13.35 & 24.28 & 3.94 & 2.37 & $0.022 *$ \\
\hline Albumin (g/dl) & 3.11 & 0.29 & 4.47 & 0.21 & 19.11 & $<0.001 * *$ \\
\hline Ferritin (ng/ml) & 513.91 & 260.06 & 133.42 & 186.66 & 5.94 & $<0.001 * *$ \\
\hline $\begin{array}{l}\text { Volume of } \\
\text { urine (ml) }\end{array}$ & 1496.0 & 1005.6 & 1384.6 & 369.3 & 0.52 & 0.61 \\
\hline eGFR & 46.10 & 21.59 & 105.05 & 10.73 & 12.22 & $<0.001 * *$ \\
\hline
\end{tabular}


Table 4: Comparison between case and control groups according to CRP Positive or Negative, pus cells, albumin in urine

\begin{tabular}{|c|c|c|c|c|c|c|}
\hline & \multicolumn{2}{|c|}{$\begin{array}{l}\text { Case group } \\
\text { (25) }\end{array}$} & \multicolumn{2}{|c|}{$\begin{array}{c}\text { Control group } \\
\text { (25) }\end{array}$} & \multirow{2}{*}{$\begin{array}{l}\text { Statistical test } \\
\qquad(\mathrm{x} 2)\end{array}$} & \multirow[t]{2}{*}{$P$ value } \\
\hline & No & $\%$ & No & $\%$ & & \\
\hline \multicolumn{7}{|l|}{ CRP } \\
\hline Positive & 21 & 84.0 & 0 & 0.0 & \multirow{2}{*}{36.21} & \multirow{2}{*}{$<0.001 * *$} \\
\hline Negative & 4 & 16.0 & 25 & 100 & & \\
\hline \multicolumn{7}{|l|}{ Pus cells } \\
\hline $6-8$ & 0 & 0.0 & 1 & 4.0 & \multirow{14}{*}{$\mathrm{FET}=42.18$} & \multirow{14}{*}{$<0.001 * *$} \\
\hline $8-10$ & 0 & 0.0 & 1 & 4.0 & & \\
\hline $10-15$ & 3 & 12.0 & 2 & 8.0 & & \\
\hline $15-20$ & 0 & 0.0 & 2 & 8.0 & & \\
\hline $20-25$ & 2 & 8.0 & 3 & 12.0 & & \\
\hline $20-30$ & 0 & 0.0 & 1 & 4.0 & & \\
\hline $25-30$ & 0 & 0.0 & 3 & 12.0 & & \\
\hline $30-40$ & 0 & 0.0 & 3 & 12.0 & & \\
\hline $40-50$ & 0 & 0.0 & 2 & 8.0 & & \\
\hline $50-60$ & 0 & 0.0 & 1 & 4.0 & & \\
\hline $50-70$ & 0 & 0.0 & 1 & 4.0 & & \\
\hline $60-80$ & 0 & 0.0 & 2 & 8.0 & & \\
\hline Over 100 & 0 & 0.0 & 3 & 12.0 & & \\
\hline Normal & 20 & 80.0 & 0 & 0.0 & & \\
\hline \multicolumn{7}{|c|}{ Albumin in urine } \\
\hline Positive & 15 & 60.0 & 0 & 0.0 & \multirow{2}{*}{$X 2=21.43$} & \multirow{2}{*}{$<0.001 * *$} \\
\hline Negative & 10 & 40.0 & 25 & 100 & & \\
\hline \multicolumn{7}{|l|}{ Albumin } \\
\hline+ & 4 & 16.0 & 0 & 0.0 & \multirow{4}{*}{$\mathrm{FET}=21.17$} & \multirow{4}{*}{$<0.001 * *$} \\
\hline++ & 7 & 28.0 & 0 & 0.0 & & \\
\hline Trace & 4 & 16.0 & 0 & 0.0 & & \\
\hline Negative & 10 & 40.0 & 25 & 100 & & \\
\hline
\end{tabular}

Table 5: Correlation between ferritin and 24hour urinary protein among case group

\begin{tabular}{ccc}
\hline & \multicolumn{2}{c}{ Ferritin } \\
Case group (25) & $\mathrm{r}$ & P value \\
& 0.512 & $0.009 * *$ \\
\hline
\end{tabular}


Benha medical journal, Vol. 38, issue 3, 2021

Table 6: Correlation between ferritin and 24hour urinary protein among control group.

Control group (25)

Ferritin
24h protein
0.02
0.94

$P$ value

Table7: Correlation between ferritin and other variables among case group

\begin{tabular}{ccc}
\hline Case group (25) & \multicolumn{2}{c}{ Ferritin } \\
& $\mathrm{r}$ & P value \\
\hline Age & -0.33 & 0.11 \\
ESR 1h & 0.32 & 0.12 \\
ESR 2h & 0.31 & 0.13 \\
CRP & 0.06 & 0.77 \\
HbA1c & 0.901 & $<0.001^{* *}$ \\
FBG & 0.12 & 0.56 \\
PPG & 0.05 & 0.82 \\
Creatinine & 0.43 & $0.033^{*}$ \\
ALT & 0.22 & 0.30 \\
Albumin & 0.04 & 0.87 \\
Volume of urine & 0.766 & $<0.001^{* *}$ \\
eGFR & -0.579 & $0.002^{* *}$ \\
Albumin in urine & 0.53 & $0.042^{*}$ \\
\hline
\end{tabular}

Table 8: Correlation between ferritin and other variables among control group

\begin{tabular}{ccc}
\hline Control group (25) & Ferritin \\
& $r$ & P value \\
\hline Age & 0.17 & 0.42 \\
ESR 1h & 0.34 & 0.09 \\
ESR 2h & 0.33 & 0.11 \\
HbA1c & 0.06 & 0.77 \\
24h protein & 0.02 & 0.94 \\
FBG & 0.19 & 0.36 \\
PPG & -0.28 & 0.18 \\
Creatinine & -0.20 & 0.35 \\
ALT & 0.17 & 0.42 \\
Albumin & 0.115 & 0.58 \\
Volume of urine & -0.123 & 0.56 \\
eGFR & 0.14 & 0.52 \\
\hline
\end{tabular}




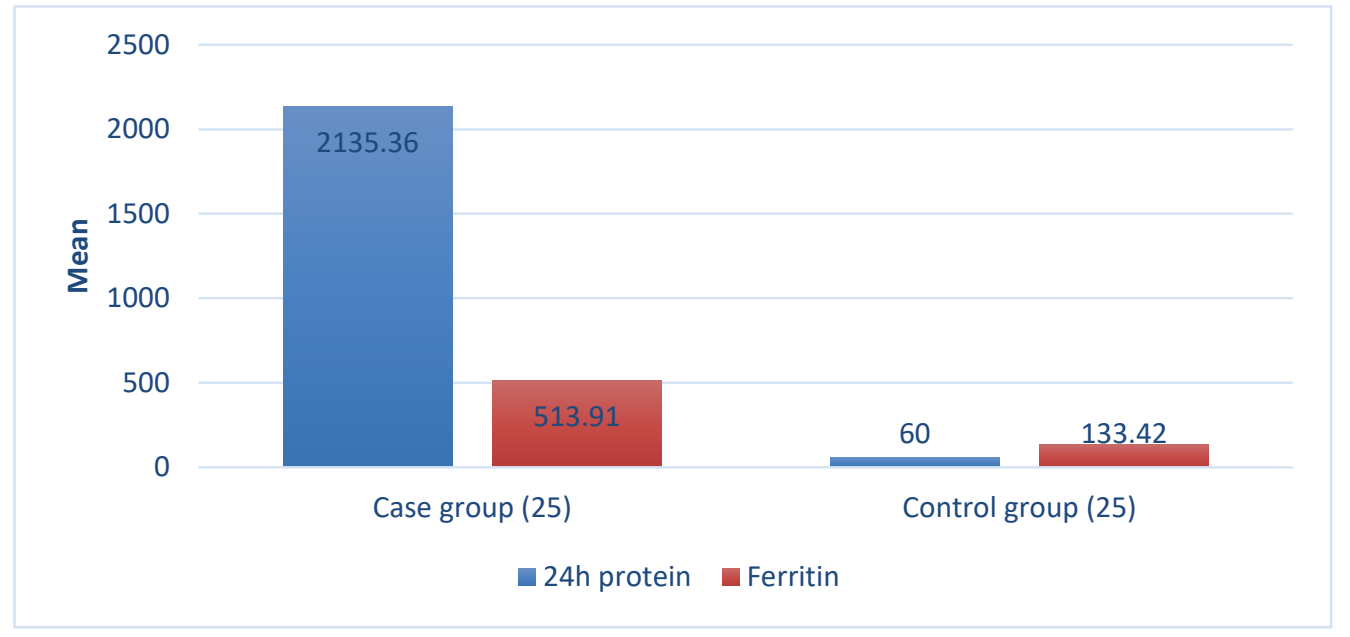

Figure (1): Comparison between case and control groups according to 24hour protein and ferritin

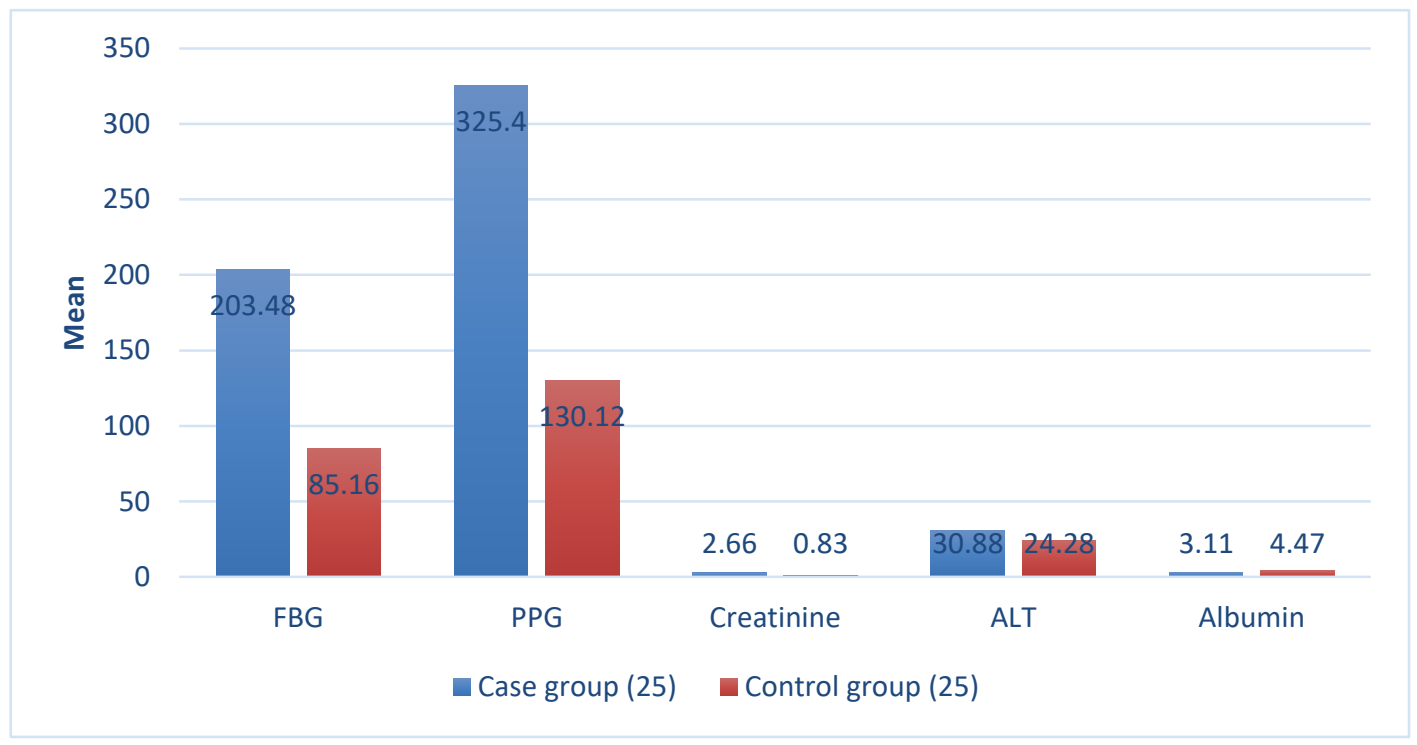

Figure (2): Comparison between case and control groups according to FBG, PPG, Creatinine, ALT, and Albumin 


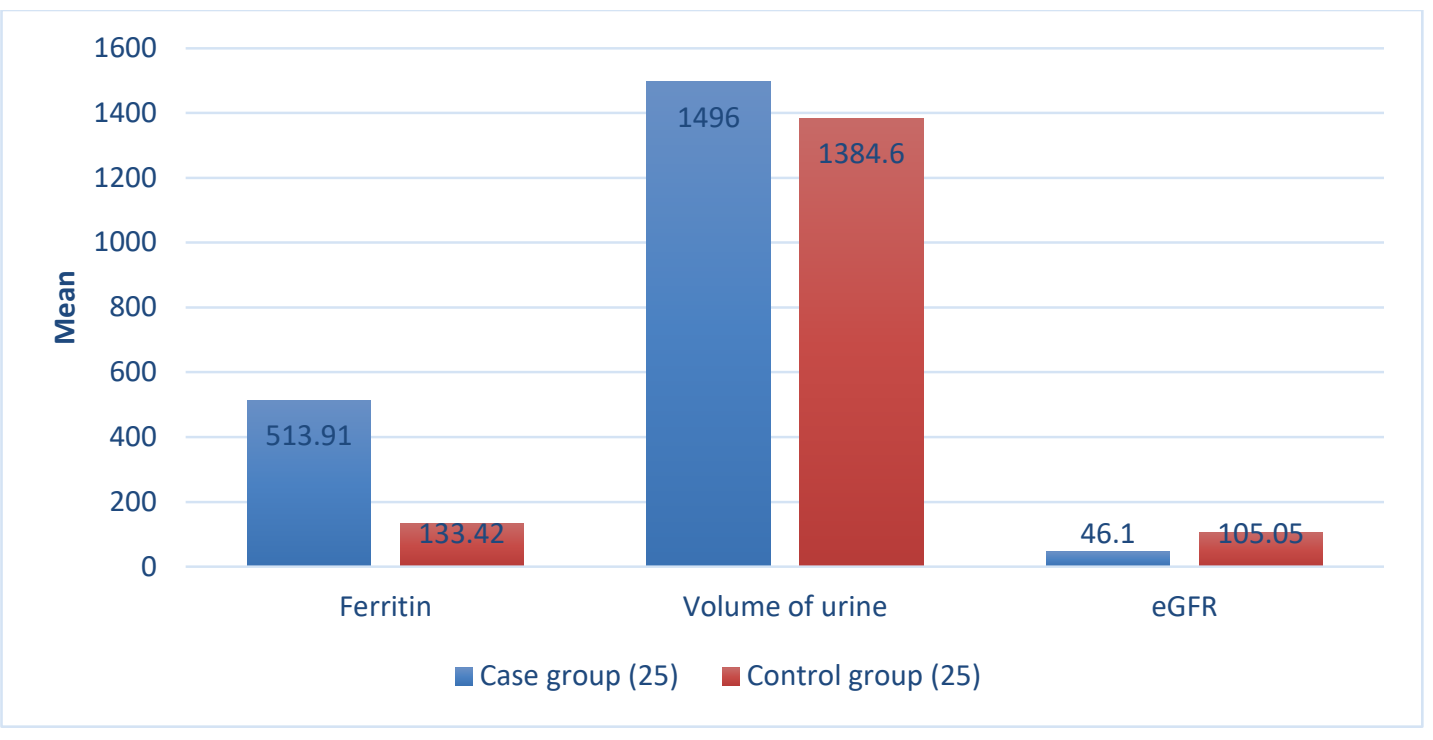

Figure (3): Comparison between case and control groups according to Ferritin, Volume of urine, eGFR

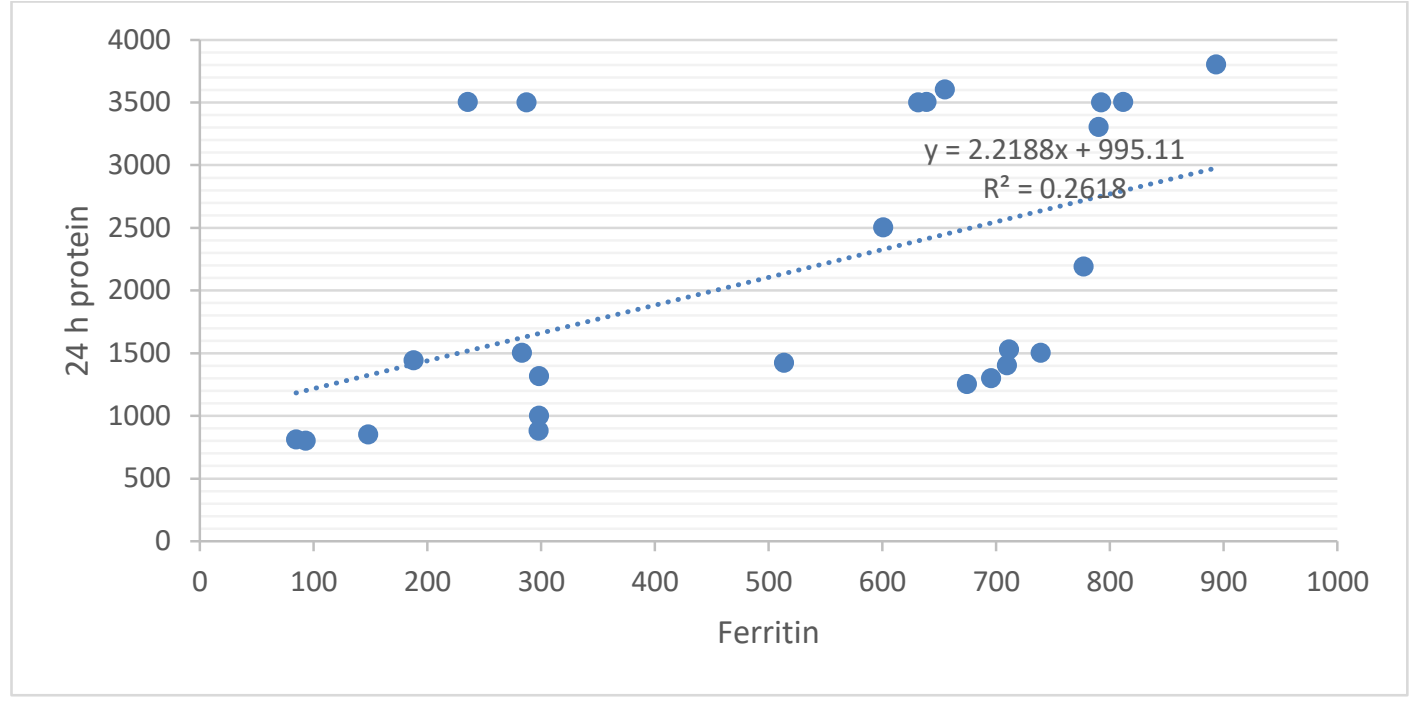

Figure (4): Relation between $24 \mathrm{~h}$ urinary protein and ferritin

\section{Discussion}

Diabetes mellitus (DM) is a chronic metabolic disorder marked by high blood sugar levels. Impaired insulin secretion, peripheral insulin resistance, or both are most likely to blame. Chronic hyperglycemia, when paired with other metabolic abnormalities in diabetics, can damage a variety of organ systems, 
resulting in dangerous complications such as microvascular (neuropathy, nephropathy, and retinopathy) and vascular implications. (6).

Complications of diabetes often occur in type 1 or type 2 diabetics, but are also the chief reason of morbidity and death. The chronic consequences of diabetes are split into two categories: microvascular and large blood vessels. Microvascular consequences might include nephropathy, neuropathy, and retinopathy, while macrovascular implications contain stroke, cardiovascular disease, and peripheral artery disease (PAD) (7).

Iron is necessary for various biological activities, but too much of it can impair numerous tissues and organs by rising production of reactive oxygen species (ROS). SF has been linked to the development of CKD in some published studies. (8) Following are several theories about iron's function in diabetes pathogenesis: (1) Iron excess has been attributed to an elevated risk of type 2 diabetes in a variety of ways. (2) a decrease in glycemic load while increasing insulin sensitivity (9).
Diabetes produces diabetic nephropathy (DN), which is one of the principal causes of end-stage kidney impairment around the world. In clinical practise, microalbuminuria is a reliable biomarker of $\mathrm{DN}$ progression (10).

The comparative present study, the mean \pm SD of diabetic patients with nephropathy, serum ferritin was $513.91 \pm 260.06(\mathrm{ng} / \mathrm{ml}) \quad$ Serum ferritin among studied group of current study show highly significant rise compared to control $(\mathrm{p}<0.001)$.

The results of serum ferritin among case group were in agreement with study done in 2020 on their study on 41 diabetic patients with diabetic nephropathy, they observed the mean $\pm \mathrm{SD}$ of patients, serum ferritin was $938 \pm 148(\mathrm{ng} / \mathrm{ml})$. Levels of serum ferritin were highly significant in diabetics with nephropathy than control $(p<0.0001)$ (11). The results in the present study were against study done in 2016, where mean of serum ferritin in case patients was $147.62 \pm 118.95(\mathrm{ng} / \mathrm{ml})$, correlation between ferritin and diabetic nephropathy was $(\mathrm{p}=.09)$ : no significant correlation (12). 
The comparative present study, the mean \pm SD of patients of eGFR $46.10 \pm 21.59$, in diabetic patients with nephropathy, eGFR is significantly lower than in the control group. (p value $<0.001$ ).

The current study's findings matched those of a study published in 2019, mean \pm sd of diabetic patients with macroalbuminuria, eGFR was $79.33 \pm 44.53$, diabetic patients with microalbuminuria eGFR $122.97 \pm$ 43.31 ( $\mathrm{ml} / \mathrm{min})$, eGFR show significantly lower in macroalbuminuria than microalbuminuria group than the control $(\mathrm{p}$ value $<0.001)(13)$. The findings of this study matched those of a 2017 study on 83 diabetic patients with nephropathy, eGFR was $\quad 61.65( \pm 20.38) \quad(\mathrm{ml} / \mathrm{min})$, (macroalbuminuria $50.17( \pm 18.38 \mathrm{ml} / \mathrm{min})$, microalbuminuria $66.50( \pm 19.25 \mathrm{ml} / \mathrm{min})$, eGFR show significantly lower in case group than the control ( $\mathrm{p}$ value $<0.001)$ (14).

The comparative present study, the mean \pm SD of diabetic patients with nephropathy, serum creatinine $2.66 \pm 1.55$. The serum creatinine level in the case group is significantly higher than in the control group (p 0.001). The current study's findings matched those of a study conducted in 2020. Serum creatinine levels in the case group were significantly higher than in the control group (p value.05) (11).

The comparative present study, the mean \pm SD of patients, 24 hour urinary protein was 2135.36 $\pm 1127.69 \quad(\mathrm{mg} / 24 \mathrm{hr})$. 24hour urinary protein in the case group was significantly higher than in the control group (p value 0.001).

The current study's findings were consistent with those of a 2016 study, show proteinuria (mg/day) group1: diabetic patients with eGFR more than $60 \mathrm{~mL} / \mathrm{min}$ with microalbuminuria, median of proteinuria $(n=37)$ 197, group2: diabetic patient with eGFR more than $60 \mathrm{~mL} / \mathrm{min}$ with albuminuria $>300 \mathrm{mg} /$ day, median of proteinuria $(n=34) 1326$, Group 3: eGFR less than $60 \mathrm{~mL} / \mathrm{min}$ with macroalbuminuria $(n=35)$, median of proteinuria $2626 \mathrm{mg} /$ day. 24 hour urinary protein show significantly higher level in group 3 more than group 2 more than group1 (p value < 0.001) (15).

The comparative present study, urinary albumin levels in the case group are significantly higher than in the control group ( $\mathrm{p}$ value 0.001 ). The findings of this study were consistent with those of a 2017 study: the mean urine-microalbuminuria 
was significantly higher among patients with DN group $(117.67 \pm 55.69 \mathrm{mg} / \mathrm{l})$ as compared to the patients without DN and healthy control groups $(12.67 \pm 6.92$ vs $13.33 \pm 7.61 \mathrm{mg} / \mathrm{l}$, respectively (16).

The current study's findings were consistent with those of a 2016 study, the median urine-microalbuminuria, in group1 (n: 37) diabetic Patients with eGFR more than $60 \mathrm{~mL} / \mathrm{min}$ with microalbuminuria 57 , group2: diabetic Patients (n34) with eGFR more than $60 \mathrm{~mL} / \mathrm{min}$ with albuminuria $>300 \mathrm{mg} /$ day, median of urinemicroalbuminuria 483, Group3: eGFR less than $60 \mathrm{~mL} / \mathrm{min}$ with macroalbuminuria $(n=35)$, median of urine-microalbuminuria 501. Urine-microalbuminuria show significantly higher in group 3 more than group2 more than group1 ( $\mathrm{p}$ value $<0.001$ ) (15).

The comparative present study, the mean \pm SD of patients, Hbalc was $8.31 \pm 0.84$. Hba1c levels in diabetic patients with nephropathy are significantly higher than in the control group ( $p$ value $<0.001$ ).

The results in the present study were in against with study done in 2016, mean of HbA1c 8.27 $\pm 2.02 \%,(\mathrm{p}=0.22)$, in that study, there was no correlation between glycemic control and ferritin level (12). The current study's findings matched those of a study conducted in 2020 , the mean \pm SD of patients, HbA1c was $($ mean $=9.2 \pm 2.02 \%)$ and $(\mathrm{p}$ value $=0.017) \mathrm{p}$ $<0.05$, that is significant (11).

The current study found a highly significant positive correlation among ferritin and HbA1c in diabetic patients with nephropathy $(\mathrm{r}=0.901, \mathrm{p}=<0.001)$, in control patients, there is no significant positive correlation $(\mathrm{r}=0.06, \mathrm{p}=0.77)$. Study done in 2019 is in agreement with my present study, a significant positive correlation among serum ferritin levels with $\mathrm{HbA1c}$ is found $(\mathrm{r}=0.43 ; \mathrm{p}=0.001)$ (9).

Study done in 2020 was in agreement with my study. In diabetic nephropathy patients, the relationship between serum ferritin and HbA1c was evaluated. The relationship between glycated haemoglobin and serum ferritin was significantly positive. $(\mathrm{r}=0.431),(\mathrm{p}$ value $=0.017)(11)$.

The current study found a highly significant positive correlation among ferritin and 24 hour protein in diabetic patients with nephropathy. $\quad(\mathrm{r}=0.512$, $\mathrm{p}=0.009$ ), in the control group, there is no 
significant positive correlation $(\mathrm{r}=0.02$, $\mathrm{p}=0.94)$.

The current study found a significant positive correlation between ferritin and creatinine in diabetic patients with nephropathy $(\mathrm{r}=0.43, \mathrm{p}=0.033)$, in the control group, there is no significant negative correlation $(\mathrm{r}=-0.20, \mathrm{p}=0.35)$.

The current study found a high negative relationship between ferritin and eGFR in diabetic patients with nephropathy( $\mathrm{r}=-$ $0.579, \mathrm{p}=0.002$ ), in the control group, there is no significant positive correlation $(\mathrm{r}=0.14, \mathrm{p}=0.52)$.

The current investigation found a significant positive association among ferritin and albumin in urine in diabetic patients with nephropathy $(\mathrm{r}=0.53$, $\mathrm{p}=0.042$ ), In the control group, there is no significant positive correlation.

In the current study, a significant positive relationship between ferritin and diabetic nephropathy (proteinuria, serum creatinine, albumin in urine as markers) is present, and a significant negative correlation with eGFR is present. The findings of this study were consistent with those of a study conducted in 2019. Serum ferritin levels have a significant positive correlation with microvascular consequences such as retinopathy, nephropathy, and neuropathy $(\mathrm{p}=0.001)(9)$.

The current study's findings matched those of a research done in 2020, diabetics with nephropathy had higher ferritin levels than diabetics without nephropathy $(\mathrm{p}<0.0001)$ (11). The results in the present study were against study done 2016, correlation between ferritin and diabetic nephropathy was $(\mathrm{p}=.09)(12)$.

\section{Conclusion}

Serum ferritin levels were found to be higher in diabetic individuals with proteinuria compared to healthy controls in this study. Furthermore, serum ferritin levels were found to be significantly correlated with kidney functions such as serum creatinine, urine albumin, and urine protein 24 hours later. Therefore, serum ferritin can be considered as an independent predicting marker of diabetic nephropathy as well as an excellent diagnostic marker for patient with clinical diabetic nephropathy

\section{References}

1. Kunutsor SK, Apekey TA, Walley J, Kain K. 2013 Ferritin levels and risk of type 2 diabetes mellitus: an updated systematic 
review and meta-analysis of prospective evidence. Diabetes/metabolism research and reviews. 2013 May;29 (4):308-18.

2. Raj S, Rajan GV. Correlation between elevated serum ferritin and HbA1c in type 2 diabetes mellitus. Int J Res Med Sci. 2013 Feb;1 (1):12-5.

3. Hsu YH, Huang MC, Chang HY, Shin SJ, Wahlqvist ML, Chang YL et al. 2013 Association between serum ferritin and microalbuminuria in Type 2 diabetes in Taiwan. Diabetic medicine 2013 Nov; 30(11):1367-73.

4. Gross JL, De Azevedo MJ, Silveiro SP, Canani LH, Caramori ML, Zelmanovitz T. 2005 Diabetic nephropathy: diagnosis, prevention, and treatment. Diabetes care 2005 Jan 1; 28(1):164-76.

5. Adams PC, Reboussin DM, Barton JC, McLaren CE, Eckfeldt JH, McLaren GD et al. 2005 Hemochromatosis and iron-overload screening in a racially diverse population. New England Journal of Medicine. 2005 Apr 28; 352 (17):1769-78.

6. Goyal R, Jialal I. 2018 Diabetes Mellitus Type 2. In : Stat Pearls Publishing, Treasure Island (FL); Jul 2018, PMID: 30020625.

7. Papatheodorou K, Edmonds M.2018 Complications of Diabetes, Journal of Diabetes Research, published 11Mars 2018, Article ID: 3086167, 4pages.

8. Wu YH, Wang SY, Li MX, He H, Yin WJ, Guo YH et al. 2020 Serum Ferritin Independently Predicts the Incidence of Chronic Kidney Disease in Patients with Type 2 Diabetes Mellitus. Diabetes, metabolic syndrome and obesity: targets and therapy. $2020 ; 13: 99$.

9. Chawla R, Bhoopathi A, Punyani H. 2019 Ferritin and serum iron as surrogate markers of poor glycemic control and microvascular complications in type 2 diabetes mellitus. International Journal of Diabetes in Developing Countries. 2019 Apr; 39(2):362-8.

10. Qi C, Mao X, Zhang Z, Wu H. 2017 Classification and differential diagnosis of diabetic nephropathy. Journal of diabetes research. 2017 Feb 20; 2017.

11. Siddappa MN, Ramprasad K. 2020 Assessment of serum Ferritin level and its correlation with $\mathrm{HbAlc}$ in Diabetic Nephropathy. Asian Journal of Medical Sciences. 2020 Feb 6;11(2):46-51.

12. Najafi L, Malek M, Valojerdi AE, Khamseh ME. 2016 Acute phase proteins and diabetes microvascular complications. International Journal of Diabetes in Developing Countries. 2016 Mar 1;36(1):107.

13. Zhang D, Ye S, Pan T. 2019 The role of serum and urinary biomarkers in the diagnosis of early diabetic nephropathy in patients with type 2 diabetes. PeerJ. 2019 Jun 11;7: e7079.

14. Al-Rubeaan K, Siddiqui K, Al-Ghonaim MA, Youssef AM, Al-Sharqawi AH, AlNaqeb D. 2017 Assessment of the diagnostic value of different biomarkers in relation to various stages of diabetic nephropathy in type 2 diabetic patients. Scientific reports. 2017 Jun 2;7(1):1-9.

15. Uzun S, Ozari M, Gursu M, Karadag S, Behlul A, Sari S, et al. 2016 Changes in the inflammatory markers with advancing stages 
Benha medical journal, Vol. 38, issue 3, 2021

of diabetic nephropathy and the role of

pentraxin-3. Renal failure. 2016 Sep

13;38(8):1193-8.

16. Tuleab SF, Abd-Allah SM, Abed MA. 2017

Evaluate the Plasma Iron Levels on Iraqi Type

2 Diabetic Nephropathy. Journal of university

of Anbar for Pure science. 2017;11(1).

To cite this article: Mohamed A .Mohamed, Saddam A.A. Hassan, Nabil E. Khattab, Samar M. Atiaa, Abdel Moneim A. Abdel Moneim. Correlation between Serum Ferritin and Proteinuria as Marker of Diabetic Nephropathy Stage in Type 2 Diabetic Patients. BMFJ 2021;38(3): 865-880. DOI: $10.21608 / \mathrm{bmfj} .2021 .80833 .1428$ 